\title{
PEMBERDAYAAN MASYARAKAT SUKU TENGGER NGADAS PONCOKUSUMO KABUPATEN MALANG DALAM MENGEMBANGKAN POTENSI TUMBUHAN OBAT DAN HASIL PERTANIAN BERBASIS “ETNOFARMASI” MENUJU TERCIPTANYA DESA MANDIRI
}

\author{
Anik Listiyana $^{1}$ dan Roihatul Mutiah ${ }^{2}$ \\ aniklis.biomed@gmail.com \\ roihatulmutiah@gmail.com

\begin{abstract}
${ }^{1}$ Program Studi Pendidikan Dokter Fakultas Kedokteran dan Ilmu-ilmu Kesehatan Universitas Islam Negeri Maulana Malik Ibrahim Malang

${ }^{2}$ Departemen Biologi Farmasi, Jurusan Farmasi Fakultas Kedokteran dan Ilmu-ilmu Kesehatan Universitas Islam Negeri Maulana Malik Ibrahim Malang
\end{abstract}

\begin{abstract}
Students as well as the next intellectual generation in society is not limited to academic obligations in the campus environment, but also should be useful in a variety of other functions in society. Students are also required to participate in community service through various forms of devotion. In this community service, lecturers with students to jointly work devotion in advancing knowledge and skills Tengger tribe in Ngadas Village District of Poncokusumo in developing the potential of medicinal plants and agricultural products based ethnopharmacy towards the creation of an independent village. Ngadas village is village with abundant natural resources, especially medicinal plants and agricultural products. Medicinal plants rare owned by the village is pronojiwo (Euchresta horsfieldii), pulosari (Alyxia reinwardtii), sintok (Cinnamomum sintoc), purwoceng (Pimpinella pruatjan), krangean (Litsea cububa Pers), flour muscles (Borreria laevis Griseb.), guava wer (Prunus persica Bl.), dringu (Acorus calamus L.). Medicinal plants have the potential to be developed and produced in large quantities in this village. Natural wealth of agricultural products is also very abundant in this village include potato, cassava, sweet potatoes and celery. But not taken into ready to eat foods products. Performed community service on 19 November 2016 in the village hall Ngadas. The activities carried out in the form of workshops begins with exposure of the material on the benefits and applications of potential medicinal plants that become local wisdom in Tengger tribe and then followed by demo making products. The product are rub medicine guava wer, muscle flour, starfruit herbal drinks and bajigur. Participants consisted of PKK Ngadas village. Good response shown by them with great enthusiasm when exposure of the material provided and when making products. In the future, this mentoring program to be developed into entrepreneurial activities of local communities to improve their welfare.
\end{abstract}

Keywords: Ethnopharmacy, Herbal products, post-harvest products, Tengger tribe, village Ngadas. 
Pemberdayaan Masyarakat Suku Tengger Ngadas Poncokusumo Kabupaten Malang dalam Mengembangkan Potensi Tumbuhan Obat dan Hasil Pertanian Berbasis "Etnofarmasi” Menuju Terciptanya Desa Mandiri

\begin{abstract}
ABSTRAK
Mahasiswa sebagai generasi penerus bangsa sekaligus elemen intelektual dalam masyarakat tidaklah dibatasi pada kewajiban akademis di lingkungan kampus saja, melainkan juga harus bisa bermanfaat pada berbagai fungsi lain di masyarakat. Mahasiswa juga dituntut untuk berperan dalam pengabdian masyarakat melalui berbagai bentuk aplikasi karya dan bakti. Pada program pengabdian ini dosen bersama mahasiswa untuk bersama-sama berkarya bakti dalam memajukan pengetahuan dan ketrampilan Suku Tengger tepatnya di Desa Ngadas Kecamatan Poncokusumo dalam mengembangkan potensi tumbuhan obat dan hasil pertanian berbasis etnofarmasi menuju terciptanya desa mandiri. Desa Ngadas ini merupakan desa dengan kekayaan alam yang sangat melimpah terutama kekayaan tanaman obat dan hasil pertanian. Tanaman obat langka yang dimiliki oleh desa ini adalah pronojiwo (Euchresta horsfieldii), pulosari (Alyxia reinwardtii), sintok (Cinnamomum sintoc), purwoceng (Pimpinella pruatjan), krangean (Litsea cububa Pers), tepung otot (Borreria laevis Griseb.), jambu wer (Prunus persica Bl.), dringu (Acorus calamus L.). Tanaman obat ini sangat berpotensi untuk dikembangan dan diproduksi dalam jumlah besar di desa ini. Kekayaan alam hasil pertanian juga sangat melimpah di desa ini diantaranya kentang, ubi ketela dan seledri. Namun belum dimanfaatkan menjadi produk makanan siap saji. Pengabdian masyarakat dilakukan pada 19 November 2016 di balai desa Ngadas, Kecamatan Poncokusumo, Malang. Kegiatan dilaksanakan dalam bentuk workshop, diawali dengan pemaparan materi mengenai manfaat dan aplikasi dari tanaman berpotensi obat yang menjadi kearifan lokal di Suku Tengger. Dilanjutkan dengan demo pembuatan produk, yakni parem jambu wer dan tepung otot, minuman herbal belimbing wuluh serta minuman bajigur. Peserta terdiri dari ibu-ibu PKK Desa Ngadas. Respon yang baik ditunjukkan oleh masyarakat Suku Tengger melalui antusiasme tinggi ketika pemaparan materi diberikan dan demo pembuatan produk dilakukan. Rencana kedepan, program pendampingan ini dapat dikembangan menjadi kegiatan kewirausahaan masyarakat setempat untuk meningkatkan kesejahtaraannya.
\end{abstract}

Kata kunci: Desa Ngadas, Etnofarmasi, , produk pasca panen, produk herbal, Suku Tengger.

\title{
PENDAHULUAN
}

Berbagai suku asli di seluruh wilayah nusantara yang hidup di sekitar hutan telah banyak yang memanfaatkan berbagai spesies tumbuhan untuk memelihara kesehatan dan pengobatan berbagai macam penyakit [1]. Setiap suku memiliki pengetahuan lokal dan tradisional dalam memanfaatkan tumbuhan obat, yaitu mulai dari spesies tumbuhan, bagian yang digunakan dan cara pengobatan untuk penyakit yang dapat disembuhkan dengan pengetahuan lokal tersebut. Pengetahuan lokal ini spesifik bagi setiap suku, sesuai dengan kondisi lingkungan tempat tinggal masing-masing suku [2]. Namun proses pewarisan pengetahuan lokal obat tradisional banyak dilakukan secara oral dan masuknya budaya modern ke masyarakat tradisional dikhawatirkan akan menyebabkan pengetahuan lokal akan mengalami erosi dan hilang [3]. Hal ini mendorong upaya pelestarian pengetahuan lokal obat tradisional sedini mungkin.

Menurut Kuntorini (2005) akhir-akhir ini penelitian tentang jenis-jenis tumbuhan yang berpotensi dan diduga berpotensi sebagai obat gencar dilakukan. Sebagai langkah awal yang sangat membantu untuk mengetahui suatu tumbuhan berkhasiat obat adalah dari pengetahuan masyarakat tradisional secara turun menurun [4]. Salah satunya dengan menggunakan pendekatan etnofarmasi.

Etnofarmasi adalah gabungan disiplin ilmu yang mempelajari tentang hubungan kebiasaan kultur dalam suatu kelompok masyarakat ditinjau dari sisi farmasinya. Di Indonesia, penelitian etnofarmasi telah dilakukan di berbagai suku, diantaranya pada Suku Muna di Kecamatan Wakarumba Kabupaten Muna Sulawesi Utara, masyarakat lokal di pulau Wawonii Sulawesi Tenggara [5] , masyarakat di sekitar Gunung Gede Pangrango [3].

Riset tentang etnofarmasi juga telah dilakukan sebelumnya oleh tim pengabdian masyarakat pada Suku Tengger Kecamatan Poncokusumo Kabupaten Malang Jawa Timur [6]. Hasil dari penelitian etnofarmasi di Suku Tengger Kecamatan Poncokusumo Kabupaten Malang Jawa Timur didapatkan beberapa tumbuhan langka dan berpotensi besar sebagai obat 
tradisional diantaranya pronojiwo (Euchresta horsfieldii), pulosari (Alyxia reinwardtii) dan sintok (Cinnamomum sintoc), purwoceng (Pimpinella pruatjan), krangean (Litsea cububa Pers.) dll. Tanaman lain yang banyak ditemukan di area wisata Gunung Bromo adalah tepung otot yang bisa didapatkan disekitar jalan menuju Gunung Bromo serta buah jambu wer yang banyak didapatkan dari ladang milik masyarakat Ngadas [6].

Area wisata Gunung Bromo juga memiliki potensi lain diantaranya adalah berlimpahnya hasil pertanian, beranekaragamnya tanaman obat dan luasnya lahan pertanian sehingga daerah ini cocok sebagai sentra produk olahan pangan dan obat tradisional berbasis wisata. Banyaknya potensi yang mendukung pada daerah ini mendorong tim pengabdian masyarakat untuk melakukan pengolahan tanaman yang ada sebagai bentuk program karya bakti. Program ini untuk tahap awal akan dilakukan di Desa Ngadas Kecamatan Poncokusumo Kabupaten Malang. Desa ini merupakan salah satu wilayah yang termasuk dalam Desa Tengger. Alasan lain dipilihnya desa ini adalah:

1. Tingkat pendidikan masih rendah

2. Tingkat religiusitas yang masih rendah

3. Tingkat ekonomi tergolong masih rendah

4. Berlimpahnya tanaman obat siap olah

5. Berlimpahnya hasil pertanian siap olah

Program ini diharapkan dapat meningkatkan kesejahteraan masyarakat karena dalam program ini dilakukan pendampingan pembelajaran Cara Pembuatan Obat Tradisonal yang Baik (CPOTB) sehingga warga mempunyai ketrampilan dalam mengolah obat tradisonal secara semi modern menjadi produk simplisia yang siap didistribusikan ke apotek dan pendampingan pembuatan produk minuman jamu semi modern yang sehat dan baik. Program ini akan kami lakukan dalam satu tim kerja dengan bidang keilmuan yang saling mendukung yaitu dari bidang Farmasi bahan alam dan Kedokteran serta melibatkan mahasiswa PKLI DAN POSDAYA UIN yang ada di desa Ngadas sehingga diharapkan program ini akan berjalan secara berkelanjutan dan multiyears. Keterlibatan mahasiswa pada program ini sangat bermanfaat dalam menumbuhkan kepekaan mahasiswa pada masalah sosial yang dihadapi masyarakat yang diharapkan mahasiswa dapat mengaplikasikan disiplin ilmunya masing-masing untuk memberikan solusi terbaik buat masyarakat.

\section{METODE}

\section{Gambaran Umum Lokasi Pengabdian}

Pengabdian masyarakat dilaksanakan di Desa Ngadas, Kecamatan Pondokusumo, Kabupaten Malang. Ngadas termasuk dalam 36 desa Suku Tengger yang terbagi dalam empat kabupaten. Desa Ngadas terletak di tengah Taman Nasional Bromo Semeru (TNBS) dan merupakan kantung dari TNBS. Berada di ketinggian mencapai 2200 mdpl dengan luas area sekitar 395 ha. Desa Ngadas memiliki topografi berbukit-bukit dan suhu udara di Desa Ngadas cenderung dingin sejuk. Ngadas ditetapkan sebagai desa wisata oleh Pemerintah Kabupaten Malang.

\section{Kondisi Masyarakat Dampingan}

Masyarakat Desa Ngadas termasuk bagian dari suku Tengger. Mata pencaharian sebagian besar warga adalah petani, pedagang di area wisata gunung Bromo, dan penyedia jasa layanan wisata. 50\% masyarakat menganut Budha Jawa, 40\% Islam, dan 10\% Hindu. Meskipun begitu, masyarakat di Desa Ngadas masih kental akan kegiatan adat yang khas.

Kondisi masyarakat Desa Ngadas saat ini yang melatarbelakangi dilaksanakannya pengabdian masyarakat adalah tingkat pendidikan, tingkat religiusitas dan tingkat ekonomi yang masih rendah namun daerahnya memiliki berbagai tanaman obat siap olah serta berbagai hasil pertanian siap olah pula. 
Pemberdayaan Masyarakat Suku Tengger Ngadas Poncokusumo Kabupaten Malang dalam Mengembangkan Potensi Tumbuhan Obat dan Hasil Pertanian Berbasis "Etnofarmasi” Menuju Terciptanya Desa Mandiri

\section{Kondisi yang Diharapkan}

Pengabdian masyarakat dilaksanakan bertujuan untuk meningkatkan produktivitas masyarakat Ngadas. Dengan adanya pemberdayaan masyarakat melalui pemanfaatan tumbuhan obat diharapkan dapat meningkatkan perekonomian masyarakat. Selain itu, dapat memberi pengetahuan bagi masyarakat mengenai pemanfaatan tumbuhan obat dengan cara yang lebih baik.

\section{Strategi Pelaksanaan}

Pemberdayaan masyarakat dilaksanakan sesuai dengan framework pelaksanaan pengabdian masyarakat, yakni:

1. Tahap Sosialisasi dan Analisis Kesehatan Warga (FGD I)

Tahapan ini dilaksanakan dengan melibatkan seluruh elemen masyarakat di Desa Ngadas melalui rembug warga tentang penyakit yang biasa diderita dan produk daerah yang biasa dimanfaatkan (etnofarmasi).

\section{Tahap FGD II}

Pada tahap ini dilakukan diskusi untuk perencanaan produk herbal yang akan dibuat sediaan simplisia dengan melihat potensi daearah, potensi budidaya, potensi pemasaran produk. 3. Tahap Pembuatan Produk Obat Tradisional

Pada tahapan ini warga dilatih untuk memproduksi obat tradisonal dalam skala industri rumah tangga mulai dari pemanenan tanaman obat, sortasi, pencucian, pengeringan, pengemasan dan pelabelan sesuai dengan dosis pemakaian. Tanaman obat yang difokuskan adalah tanaman obat yang melimpah pada desa ngadas sehingga memungkinkan untuk dijual dengan kualitas terjamin.

\section{Tahap Pemasaran Produk}

Dilakukan pendampingan promosi dan penjualan baik secara langsung didaerah wisata maupun melalui media internet pada lingkungan wisata dan lingkungan kampus.

\section{HASIL DAN PEMBAHASAN \\ HASIL}

\section{Gambaran kegiatan}

Pengabdian masyarakat dilaksanakan pada tanggal 19 November 2016, yang 2 minggu sebelumnya telah diawali dengan dilakukannya survey lokasi kemudian dilanjutkan pertemuan dengan warga sebagai tahap sosialisasi dan analisis kesehatan warga. Pertemuan ini dilakukan dalam bentuk FGD I. Kegiatan kedua adalah FGD II yang kemudian dilanjutkan dengan pencarian bahan baku simplisia. Kegiatan pokok setelah dilakukannya FGD adalah tahap pembuatan produk obat tradisional. Sekitar 30 ibu-ibu PKK duduk di dalam balai desa untuk mengikuti pelaksanaan pendampingan pembuatan simplisia tanaman dan minuman herbal. Ibuibu PKK tersebut juga turut membawa anak-anaknya untuk turut belajar pembuatan simplisia dan minuman herbal. Sebelum pembuatan simplisia dan minuman herbal, kegiatan diawali dengan dilakukan pengenalan terhadap jenis tanaman yang digunakan pada pendampingan tersebut. Dalam pembuatan simplisia buah jambu wer, yakni buah jambu wer mutu bagus yang diperoleh di potong tipis-tipis dan dicuci sampai bersih. Selanjutnya dikeringkan menggunakan oven suhu $30^{\circ} \mathrm{C}$ selama $5 \times 24$ jam. Apabila tidak terdapat oven, maka dapat digunakan panas matahari untuk mengeringkannya, akan tetapi proses pemanasan buah tidak boleh terkena sinar matahari langsung, tetapi ditutup kain hitam terlebih dahulu. Buah kering yang diperoleh kemudian diserbuk. Serbuk yang dihasilkan disimpan dalam plastik kedap udara (plastik klip) dan dilabeli "simplisia buah jambu wer" dengan dicantumkan dosis pemakaian agar tidak tertukar dengan simplisia yang lain. Dalam pembuatan simplisia herba tepung otot juga sama seperti pembuatan simplisia jambu wer. 


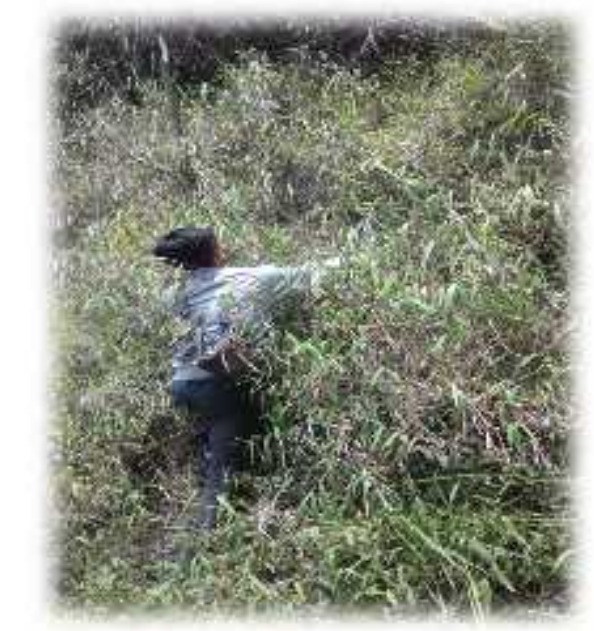

Tepung Otot (Burreria laevis Griscb.)

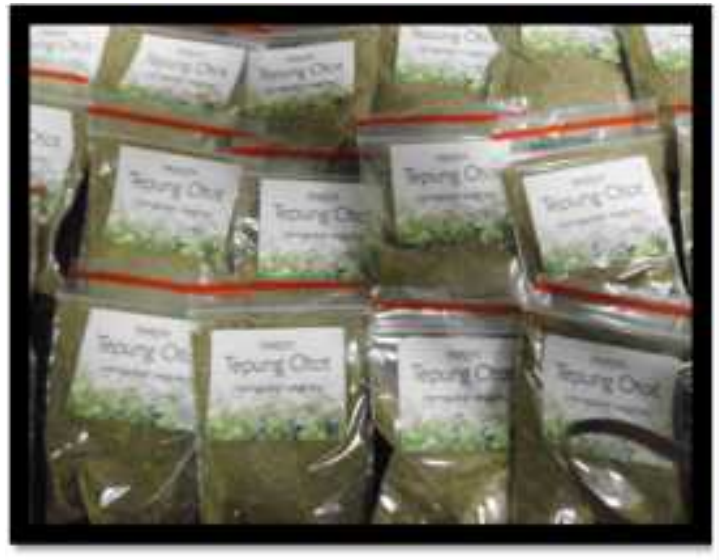

Parcm Tepung Otot untuk pegal linu

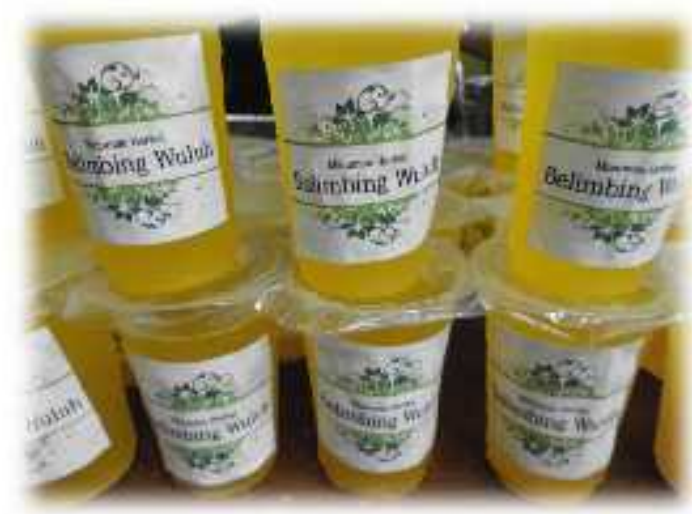

Biowuluh untuk hipertensi

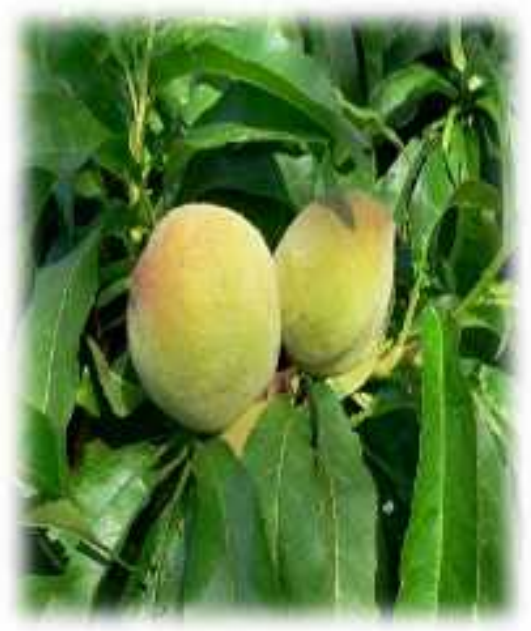

Jambu Wer (Prumus persica 131.$)$

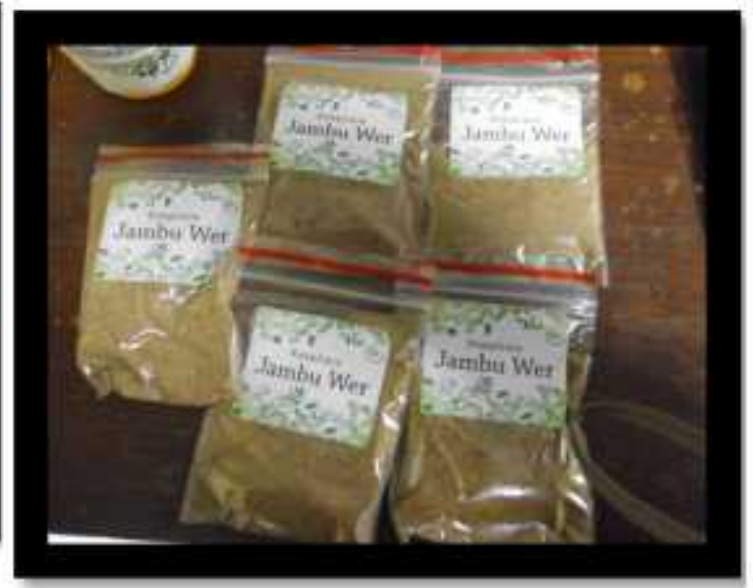

Obat diare dari Jambu Wer

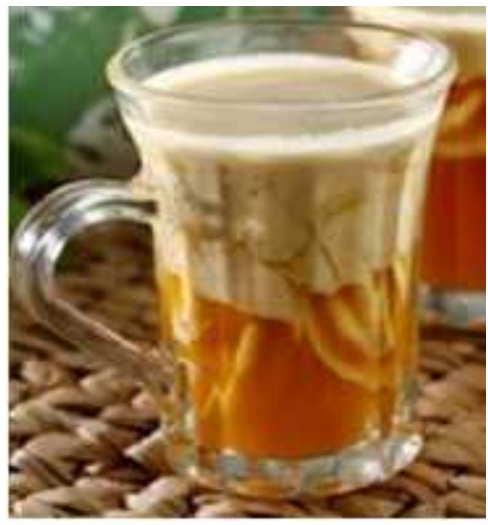

Wedang Bajigur untuk menghangatkan tubuh

Tepung otot biasanya digunakan untuk jamu pegal linu oleh masyarakat setempat, yakni dengan cara menggosokkan bagian apapun tanaman tepung otot ke bagian tubuh yang merasa nyeri (pegal linu). Dengan dibuat simplisia ini diharapkan dapat mempermudah masyarakat dalam penggunaan tepung otot sebagai obat. karena bentuk simplisia memudahkan penyimpanan dan penggunaannya. Simplisia tepung otot yang jadi dapat ditambah minyak gandapura ketika akan dioleskan ke bagian tubuh yang nyeri. 
Jambu wer sudah sering dimanfaatkan oleh masyarakat setempat untuk mengobati diare. Jambu wer yang digunakan adalah jambu yang masih muda dan berasa sepat. Dimungkinkan adanya rasa sepat karena ada senyawa tanin yang berkhasiat sebagai antidiare seperti yang terdapat pada jambu biji [8].

Proses pembuatan simplisia dilakukan oleh peserta dengan antusias. Setelah pembuatan produk simplisia dilakukan pendampingan pembuatan minuman belimbing wuluh dan bajigur. Wilayah desa Ngadas yang dekat dengan area wisata Gunung Bromo sangat potensial untuk dijadikan pemasaran produk lokal. Selain itu, wilayah Bromo juga cenderung memiliki suhu dingin. Minuman bajigur umumnya belum populer di desa Ngadas dan belum dijual di lokasilokasi wisata. Padahal, minuman ini sangat baik untuk menjaga kehangatan tubuh. Potensi minuman bajigur untuk dijual di lokasi-lokasi wisata sangat besar, mengingat minuman bajigur sudah populer di wilayah-wilayah dataran tinggi lain, khususnya daerah Jawa Barat.

Pembuatan minuman belimbing wuluh dilakukan dengan cara dekok. Mulanya masyarakat ragu sebab ternyata belimbing wuluh jarang ditemukan di wilayah sekitar. Namun, setelah dilakukan diskusi, permasalahan pun dapat diatasi. Rasa asam pada belimbing wuluh dapat diganti dengan tumbuhan lain, seperti asam, yang mudah ditemukan di desa Ngadas.

Tahap selanjutnya setelah pendampingan, masyarakat diharapkan dapat melakukan produksi secara mandiri produk herbal dari bahan yang tersedia dilingkungan sekitar serta dapat memasarkannya secara mandiri juga di area wisata Gunung Bromo. Pihak stakeholder memantau pelaksanaan produksi melalui komunikasi telepon dengan ketua PKK. Permasalahan yang dialami selama proses pembuatan produk dikomunikasikan, dalam jangka waktu tertentu pihak stakeholder melakukan kunjungan ke Desa Ngadas dalam rangka menyediakan bahan untuk pemasaran (misal: botol, stiker produk, dan lain-lain).

Hasil produk simplisia dan parem tepung otot dipasarkan murni dengan bantuan stakeholder. Pemasaran dilakukan di kampus dan wilayah sekitar, sedangkan hasil produk minuman dekok (mulanya belimbing wuluh kini diganti dengan asam) dipasarkan di area wisata Gunung Bromo dan di kampus. Sedangkan untuk minuman bajigur dipasarkan secara lokal di area wisata Gunung Bromo.

\section{Dinamika Keilmuan}

Dalam proses pemberdayaan masyarakat, masih ditemukan hambatan-hambatan yang berkaitan dengan kajian teori yang tidak dapat diaplikasikan secara nyata. Sebagai contoh proses pembuatan simplisia yang secara teoritis dilakukan dengan pemanasan kering (oven), namun masyarakat masih melakukan secara tradisional yaitu menggunakan pemanasan dengan sinar matahari.

Proses produksi produk-produk lain tidak ditemukan adanya hambatan berarti. Untuk pemasokan bahan-bahan produksi seperti gelas plastik, botol, stiker, dibantu oleh pihak stakeholder. Meskipun belum bisa sepenuhnya memenuhi aspek CPOTB, namun proses produksi diusahakan mengacu pada CPOTB.

\section{Teori yang Dihasilkan dari Pendampingan Komunitas}

Simplisia buah jambu wer dan simplisia tepung otot dapat diproduksi secara massal oleh masyarakat Desa Ngadas, begitu pula dengan minuman herbal kunyit asam sebagai pengganti minuman blimbing wuluh dan wedang bajigur juga dapat dikembangkan menjadi bentuk wirausaha dan diproduksi secara masal, karena ketersediaan bahan baku yang mumpuni di wilayah tersebut.

\section{PEMBAHASAN}

Rentang ketinggian yang begitu lebar memungkinkan kawasan konservasi Taman Nasional Bromo Tengger Semeru memiliki keanekaragaman hayati yang cukup tinggi dengan karakter vegetasi yang khas [9]. Di wilayah Taman Nasional Bromo Tengger Semeru terdapat kurang lebih 600 jenis flora, dan yang banyak dijumpai antara lain: mentigi (Vaccinium 
varingaefolium), akasia (Acacia decurrens), kemlandingan gunung (Albitzia lophanta), cemara gunung (Casuarina junghuniana) dan adas (Funiculum vulgare). Begitu juga di hutan Semeru bagian selatan terdapat 157 jenis anggrek seperti Malaxis purpureonervosa, Maleola witteana dan Liparis rhodochila. Di samping jenis-jenis di atas terdapat pula jenis tumbuhan pegunungan Tengger di antaranya pakis uling (Cyathea Tenggeriensis), putihan (Buddleja asiatica), senduro (Anaphalis sp.) dan anting-anting (Fuchsia magallanica), jamuju (Dacrycarpus imbricatus), cemara gunung (Casuarina sp.), eidelweis (Anaphalis javanica), berbagai jenis anggrek dan jenis rumput langka (Styphelia pungieus) [9].

Hidayat dan Risna (2007) menemukan 13 jenis tumbuhan obat di resort Ranu Pani, Senduro dan Pronojiwo. Tiga jenis diantaranya termasuk kategori tumbuhan obat langka yaitu pronojiwo (Euchresta horsfieldii), pulosari (Alyxia reinwardtii) dan sintok (Cinnamomum sintoc) di kawasan Taman Nasional Bromo Tengger Semeru, dan satu jenis tumbuhan obat langka yaitu purwoceng (Pimpinella pruatjan) ditemukan di perkebunan penduduk.

Keadaan alam sebagaimana yang telah diuraikan, terutama dari jenis tanah, keadaan tanah, dan suhu udara daerah Tengger akan mempengaruhi dan sangat menentukan keberadaan jenis tumbuhan yang dapat tumbuh subur secara alami. Tumbuh-tumbuhan yang dapat hidup subur di kawasan Tengger sangat beragam, mulai dari tanaman pohon besar sampai tanaman herba yang tergolong kecil. Tanaman pohon, seperti akasia, cemara gunung, bambu dapat dijumpai di sekitar pegunungan Tengger. Sedangkan tanaman herba, termasuk jenis sayuran sangat beragam, misalnya kentang, kubis, seledri, wortel, jagung, ubi ketela, bawang putih, bawang prei, sawi, dan tomat yang merupakan hasil pertanian masyarakat Tengger [7].

\section{Follow Up}

Tindak lanjut yang dilakukan dari kegiatan pengabdian masyarakat ini yakni:

1. Pemantauan kegiatan produksi.

2. Membantu pemasaran produk-produk yang meliputi produk minuman kunyit asam, simplisia jambu wer, parem tepung otot dan wedang bajigur.

Adapun manajemen pelaksanaan kegiatan produksi sudah diolah dan ditata oleh ibu-ibu PKK Desa Ngadas sebagai sasaran perwakilan yang menerima sosialisasi sekaligus pembinaan selama pelaksanaan pengabdian masyarakat berlangsung.

\section{KESIMPULAN}

Dari pemaparan hasil pelaksanaaan pemberdayaan masyarakat Desa Tengger dalam pemanfaatan sumber daya tumbuhan berkhasiat secara etnofarmasi, dapat disimpulkan bahwa telah berhasil diproduksi produk lokal oleh masyarakat Desa Ngadas yang berupa parem tepung otot, simplisia jambu wer, minuman kunyit asam, dan minuman bajigur. Adapun permasalahan yang terjadi selama proses pelaksanaan pendampingan dapat diatasi dengan melakukan penyesuaian antara teori dengan realita masyarakat. Proses produksi dilaksanakan secara mandiri oleh masyarakat Desa Ngadas dengan pemantauan jarak jauh dan pemasaran produk dibantu oleh pihak stakeholder.

\section{Ucapan terimakasih}

Penulis mengucapkan terimakasih kepada Dirjen Pendidikan Tinggi Islam Kementerian Agama RI atas biaya dalam penyelenggaraan pengabdian masyarakat ini. 


\section{DAFTAR PUSTAKA}

[1] Zuhud, E.A.M. Potensi Hutan Tropika Indonesia Sebagai Penyangga Bahan Obat Alam Untuk Kesehatan Bangsa. Fakultas Kehutanan Institut Pertanian Bogor. Bogor.2008

[2] Muktiningsih, Syahrul, Harsana, Budhi, dan Panjaitan. Review Tanaman Obat Yang Digunakan Oleh Pengobat Tradisional Di Sumatra Utara,Sumatra Selatan, Bali dan Sulawesi Selatan. Media Litbang Kesehatan. 11 (4): 25. 2001

[3] Rosita, Rostiana, Pribadi, dan Hernani. Penggalian IPTEK Etnomedisin di Gunung Gede Pangrango. Bul. Littro. 18 (1): 13- 28. 207

[4] Kuntorini, E.M. Botani Ekonomi Suku Zingiberaceae Sebagai Obat Tradisional Oleh Masyarakat di Kotamadya Banjarbaru. Bioscientiae. 2 (1): 25- 36. 2005

[5] Windardi, Rahayu, Uji, dan Rustiami. Pemanfaatan Tumbuhan sebagai Bahan Obat Oleh Masyarakat Lokal Suku Muna Di Kecamatan Wakarumba, Kabupaten Muna, Sulawesi Utara. Biodiversitas. 7 (4): 333-339. 2006

[6] Pamungkas, R.P. Etnofarmasi Suku Tengger Kecamatan Poncokusumo Kabupaten Malang. Tidak Dipublikasikan. Skripsi. Jember: Fakultas Farmasi Universitas Jember. 2011

[7] Sutarto, A. Sekilas tentang Masyarakat Tengger. [26 April 2009]

[8] Harborne, T. Metode Fitokimia. Bandung: ITB Press.1987

[9] Hidayat S dan Risna RA. Kajian Ekologi Tumbuhan Obat Langka di Taman Nasional Bromo Tengger Semeru Ecological Research on Endangered Medicinal Plants in Bromo Tengger Semeru National Park. Biodiversitas. 8 (3): 169-180. 2007 